\title{
An Inquiry into the Causal Relationship among Leisure Vacation, Depression, and Absence from Work
}

\author{
Kimio TARUMI ${ }^{1}$ and Akihito HAGIHARA ${ }^{2}$ \\ ${ }^{1}$ Section of Postgraduate Guidance, University of Occupational and Environmental Health, Japan. \\ Yahatanishi-ku, Kitakyushu 807-8555, Japan \\ ${ }^{2}$ Department of Health Services Management and Policy, Kyushu University Graduate School of \\ Medicine. Higashi-ku, Fukuoka 812-8582, Japan
}

Abstract: Depression is one of the most prevalent psychological health problems in occupational settings. Through literature review and the experience of previous investigations, it is now presumed that depression could mediate the association between workload and absence from work. In order to examine the above relationship, a follow-up investigation was conducted using male white-collar employees. The authors have been examining the association between work-related factors and employee health for some years, and vacation has become recognized as one of the important candidates for alleviating psychological problems in the workplace. In July 1996, the chance of leisure vacations within the past year and the presence of depression were examined by a self-administrated questionnaire. The subjects were followed-up for the rest of the year and absence from work was monitored. By analyzing 357 eligible subjects aged 20-59 years, the causal association between leisure vacation, depression, and absence from work was examined. Through correlation and log-linear analysis, the following findings were explored: The decrease of leisure vacation chances was correlated with the presence of depression, and depression contributed to an increase in the absence from work after adjustment was made for possible confounding factors. Leisure vacation could be independent of other work-related factors such as working hours, and it seemed to be significant to investigate positive effects of leisure vacation on psychological well-being in the workplace.

Key words:leisure, vacation, depression, absence from work.

(Received 1 April 1999, accepted 19 August 1999 )

\section{Introduction}

It has been pointed out that depression is one of the major psychological health problems in the community $[1-3]$ and at the work site $[4-7]$. These epidemiologic surveys revealed a high prevalence of depression, and, therefore, it would be appropriate that depression 
be taken into account first for determining psychological health status. Through reviewing epidemiologic studies on depression, we paid special attention to the two natures: one was the fact that depression covered a wider rage of psychological disturbances, and another was that socioeconomic problems were widely explored with depression as consequent effects.

As for the former, depression was studied in the broad sense; not only clinical depression but also subclinical forms of depressive disorders in those studies mentioned above, and it was proved to be a common form of psychological ill-being. McDowell and Kristjansson [8] state that depression is "a syndrome rather than a single entity." Socioeconomic problems were another characteristic of the latter, and sick leave or absence from work was especially a matter of concern. For example, in large epidemiologic investigations $[1-3,9$, $10]$, sick leave was a representative indicator for work productivity in relation to depression. An ECA (Epidemiologic Catchment Area) study [1] estimated that $17.8 \%$ of working days were lost due to depressive symptoms in the community using a population attributable risk indicator. A DEPRES (Depression Research in European Society) study [3] also reported $17 \%$ of a 6-month prevalence with depression across six European countries, and the mean days of sick leave were found to decrease linearly along with the descending grade of depression categories.

Those above investigations were community-based studies, and the association between depression measured by different scales and sick leave is obvious because those who suffer from depression are more likely to lose their jobs. The Whitehall study $[11,12]$ is a longstanding epidemiologic survey in occupational settings in which the effects of socioeconomic factors were observed in relation to the health of British civil servants. In the Whitehall study II [12], psychiatric symptoms and psychosocial work characteristic variables were examined together, and both were significantly associated with sick leave. Though the General Health Questionnaire was the measure for assessing psychiatric symptoms, depression was included in it as an identifiable element $[8,13]$. That is, epidemiologic researches explicitly suggested the possible association between depression and sick leave.

On the other hand, what do workers think to be important in order to prevent or cope with their own depression in the workplace? Whippen et al . [14] examined burnout in U. S. oncologists. They reported that $56 \%$ of oncologists complained of some degree of burnout, and $69 \%$ expressed the need of more vacation and personal time to alleviate their burnout. Even though burnout and depression are different phenomena, their overlap to a certain extent is pointed out [15]. In an investigation of health status and job and life satisfaction among academic and clinical faculties [16], vacation was also set as a composite of work characteristics. Emotional well-being and job satisfaction among Canadian emergency physicians were examined [17]. Increased holiday vacations positively contributed to their job satisfaction level, and it was concluded that time away from clinical practice was important. American sociologist J. B. Schor [18] also discussed how to "exit the squirrel cage of overwork." Though these investigations do not treat depression directly, the results seem to sug- 
gest that vacation or rest must be one of the most significant factors affecting the psychological health status, including depression, of workers.

The authors [19-23] have been examining work stress in male white-collar workers for several years. Lifestyle, personality or working conditions have been investigated in relation to employee health, but vacation has not yet been given sufficient attention and, therefore, not planned into the study design. The authors previously participated in a review of the literature examining the relationship between vacation and health [24]. Vacation or synonymous conditions which were expressed in such words as leisure, rest, respite and so on were confirmed to be related to both the physical and psychological health status. Scrutinizing our studies regarding work and stress and taking the above-mentioned experiences in the literature review into account, an investigation on the effects of vacations on employee health was conducted [21]. Through a cross-sectional investigation, two findings came up regarding vacation: Vacations taken as leisure were independent work-related factors, and were significantly related to psychological health status after adjustment was made for possible confounding factors. Therefore, for the next step, that is, focusing on a specific psychological factor, a follow-up investigation was needed to confirm the positive effects of vacation on employees' well-being.

Even though there are reports which suggest the relationship between vacation or rest and health effects, there are unexpectedly few studies which directly focus on the association between vacation and health status. This is commonly recognized by researchers who have investigated vacation and health, though we have also noticed a dearth of such kinds of studies through reviewing related literature $[25-27]$. Through the overview of the association between vacation, depression, and social consequences, the following pathway can be assumed: that is, a lack of vacations possibly raises the prevalence of depression in an employee population, and depression prevents employees from going to work. In the present study, the authors conducted a follow-up investigation to identify the causal association between vacation, depression and absence from work using male white-collar employees.

Based on the experience in our previous studies [21], the chance of leisure vacations during the past year and the presence of depression in the subjective group was examined by a questionnaire survey. The subjects investigated were thereafter followed-up for a one-year period, and the number of days of absence from work due to fatigue or illness was examined. There are some reports that have examined the association of depression and absence from work as mentioned above, but few studies exist which have examined the association between vacation and depression as described above. The role of vacation on workers' depression and consequent absence from work, in other words, the causal link of the relationship between vacation and absence from work mediated by depression, is examined through the prospective investigation. 


\section{Subjects and Methods}

\section{Subjects}

The subjects investigated were male white-collar employees who were working at the headquarters of a Japanese industrial company located in the downtown area of a metropolitan city in Japan. All of the employees were engaged in managerial, clerical, or engineering work and had been employed for at least one year or more by the company at the time of the study in July 1996.

In July 1996 and 1997 respectively, the subjects were investigated using a selfadministrated questionnaire which was designed and prepared by the authors. The questionnaires were distributed to the subjects, and they were required to complete it within one month and return it themselves to the staff in charge. The staff then checked the questionnaire and asked the subjects to complete any missing answers, though the purpose of the investigation was included in the questionnaire and respondents were allowed to refuse to answer.

The number of male employees who were assigned to the office and surveyed was 502 in July 1996. Because of their different employment conditions, one employee aged 19 years and two who were 60 years or older at the time of the survey were excluded. The remaining 499 subjects aged 20-59 years were followed-up during the next one-year period, from July 1996 to July 1997 . The company had work sites and branches in domestic and overseas areas and white-collar employees usually moved to different workplaces frequently for reasons of human resource management. However, after one year of follow-up, 365 of the 499 subjects were still in the same office. In the process of selecting the subjects for analysis, eight more subjects were excluded: three in 1996 and four in 1997 due to inappropriate responses, and one because of refusal in 1997. Finally, 357 subjects were eligible for analysis.

\section{Items questioned}

The questionnaire used for the investigation in 1996 was composed of the following parts: i) The number of vacation chances taken as leisure within the past one-year period. ii) The Goldberg's 18-items (G-18) [28] as the scale for assessing depression. iii) Average working hours a day in a usual workweek. iv) Demographic items such as sex, date of birth, and marital status. In the 1997 survey, the same items as above except the G-18 were also asked, and the following question was added: v) The number of days of absence from work due to fatigue and/or diseases within the past year. Though other work-related questions were also included, those were diverted into other analyses.

1) Leisure vacation

Employees are guaranteed vacation legally and through collective agreement for hu- 
manitarian purposes [29]. Yearly vacations consist of two-day weekends, national holidays, and paid annual holidays of 20-40 days. Moreover, a few days of annual paid vacations during New Year's, and spring and summer seasons are usually prepared in accordance with yearly social customs in Japan. Despite such an institutional establishment, labor statistics indicate that Japanese workers take a fewer number of paid holidays than those allowed by the employers [30]. For example, employees do not usually take all their paid holidays. Only $53.9 \%$ of holidays given were taken by employees in 1994, and this figure has shown little change in recent years. Moreover, it has been pointed out that vacations or holidays are often diverted to purposes other than leisure such as work-related receptions or ceremonial occasions because of the Japanese work ethic $[18,31-33]$. Therefore, the number of days taken for vacation is not a suitable monitor. What is to be examined in relation to health is how much vacation time employees are able to take free from work-related events, that is, to measure actual vacations that are completely leisure time.

English sociologist S. Parker [34] inquired into the relationship between work and leisure in detail, and in contrast to work, he considered the substantial function of leisure as free time taken for the purposes of rest, diversion, and self-enlargement, citing Dumazedier's discussion [35]. Through the consideration above, leisure vacation becomes detached from work and can be investigated for its health effects as an independent variable in the workplace. Then, the number of chances of leisure vacations taken within the past year was examined in the questionnaire with a response category of twice or more, once, or none a year, always considering the yearly social customs as above-mentioned. The question item is also described in detail elsewhere [21].

\section{2 ) Working hours}

In the analysis of a causal association, temporality, dose-response relationship and confounding factors always have to be taken into consideration [36]. The former two elements, temporality and dose-response relationship, were taken into account in the follow-up study design and analysis methods (see below). In our previous investigation, which examined workload factors and employee health, working hours were one of the most possible candidates of confounding factors in relation to vacation [21], and it was also considered as a possible confounding factor in this investigation. Other psychological or working condition factors other than working hours, for example, job demands, control and social support were not analyzed because of no simultaneous association with both leisure vacation and depression or absence from work in the experience of our previous study. The question of average working hours per day in a usual workweek was asked. The response categories were $8,9,10$ and 11 hours or more.

\section{3 ) Depression}

There are certain measurement scales to detect depression, but accessibility to the response and the number of questions had to be taken into account in conducting the survey. The G-18 was finally adopted to check depression. Goldberg developed the questionnaire, 
and the reliability and validity were reported $[28,37]$. The questions consist of two nineitem groups with response categories of yes or no. Each group assesses the presence of depression and anxiety respectively. In this analysis, however, only depression was considered for further analysis. Depression is a major psychological problem in occupational settings as described in the Introduction, and on the other hand, anxiety is reported to show a less clear picture in relation to social factors [38]. In the case where subjects responded with "yes" to any of the first four questions, the number of "yes" for the remaining five questions was counted. Those who had a count of two or more "yes" responses were judged to be depressive. Depression judged from the G-18 is interpreted as those having "a $50 \%$ chance of having a clinically important disturbance, " and it does not necessarily mean clinical depression.

4) Absence from work

It is widely known that Japanese employees tend to substitute annual paid holidays for sick leave [33]. The records of absent days registered and filed in the companies are for the purpose of calculating monthly wages, and those records do not provide information about whether the holidays taken are spent for sick leave or leisure. Therefore, the number of days of absence from work due to fatigue and/or diseases within the past one-year period was asked in the self-reported questionnaire. The response categories were $0,0.5-3,4-6$, and 7 days or more a year. This question item seemed to indicate the possibility of subjects not being able to distinguish sick leave from leisure vacation. In the questionnaire, therefore, the question about sick leave was placed before the vacation questions, as there was the possibility that subjects would think vacation also includes days absent due to sickness.

\section{Analysis methods}

\section{1) Data preparation}

The response categories for leisure vacation were none, once a year and twice or more, and they were included in the analysis without any changes. Before analyzing the data, the response categories of other items were arranged for reasons of convenience and from the viewpoint of practical application of the results. i) The number of days of absence from work was divided into three categories: none, half a day to 3 days, and 4 days or more. ii) The number of working hours was dichotomized into two categories: less than 10 hours a day and 10 hours or more. Through reviewing the literature about working hours and worker health, Spurgeon et al . stated that health effects were concerned with working hours beyond 50 hours a week [39], and this approximately corresponded to 10 or more working hours a day. iii) The responses in the G-18 were summarized into whether there was suffering from depression or not according to the original indication [28]. iv) Age was grouped into three categories taking into account job advancement or the seniority system in the company, that is, $20-34,35-44$, and $45-59$ years of age. The age of a subject on the last day of December 1996 was used. 


\section{2) Analysis procedures}

First, the subjects investigated in 1996 and those eligible for analysis were compared based on age, the number of leisure vacation chances, the presence of depression, and working hours to check attrition bias. The Cochran-Mantel-Haenszel statistics tested the differences in the subjects' distribution among those factors.

Next, according to the assumed relationship in the Introduction, the association between vacation and depression, depression and absence from work, and the integrated association among them were examined: i) The prevalence of depression was indicated according to leisure vacation chances and working hours categories based on age groups. These associations were tested using the chi-squared statistics. The Cochran-Armitage test checked linearity of associations. The adjusted associations for age and working hours were also tested using the Cochran-Mantel-Haenszel statistics. ii) A contingency table for depression and absence from work was made up based on age, merging of the survey data in 1996 and 1997 , and then the chi-squared test checked the significance of the association between them. The Cochran-Mantel-Haenszel test checked the associations among those two factors, adjusted for age. In this case, depression had only two categories, suffering or not, and linearity that could not be tested. iii) A breakdown of the subjects according to the categories of leisure vacation chances, depression, and absence from work was made in order to observe the association among those factors in one contingency table. iv) A log-linear analysis [4042] was conducted to explain the integrated association between vacation, depression and absence from work using the CATMOD procedure in the SAS program [43]. The likelihood ratio statistics tested some models derived from the combination of the variables. The model which had the least number of items and satisfied the criteria for the goodness-of-fit of the model was pursued. In the last two analyses, iii) and iv), age and working hours were not taken into account because they were not related to either the cause or effect variables in the previous analysis (see the Results 2.), and accordingly not possible confounding factors [44].

\section{Results}

1. The subjects surveyed and those analyzed, and overviews of the factors

As seen in Table 1, there were no significant differences in the response distributions of the factors analyzed between the subjects surveyed in 1996 and those eligible for further analysis who were followed-up during the next one-year period.

The frequency distribution of the factors in the subjects analyzed is also indicated in the lower row according to the age groups. In the 20-34 age group, the percentage of those who made use of two or more leisure vacation chances within the past year was the highest. The percentage of those who replied they took no leisure vacation chances was $19.6 \%$ of all the subjects. The percentages of those who indicated depression were much the same 
Table 1. Frequency distribution of leisure vacation chances, depression and working hours in 1996 and 1997 , and absence from work from July 1996 to June 1997

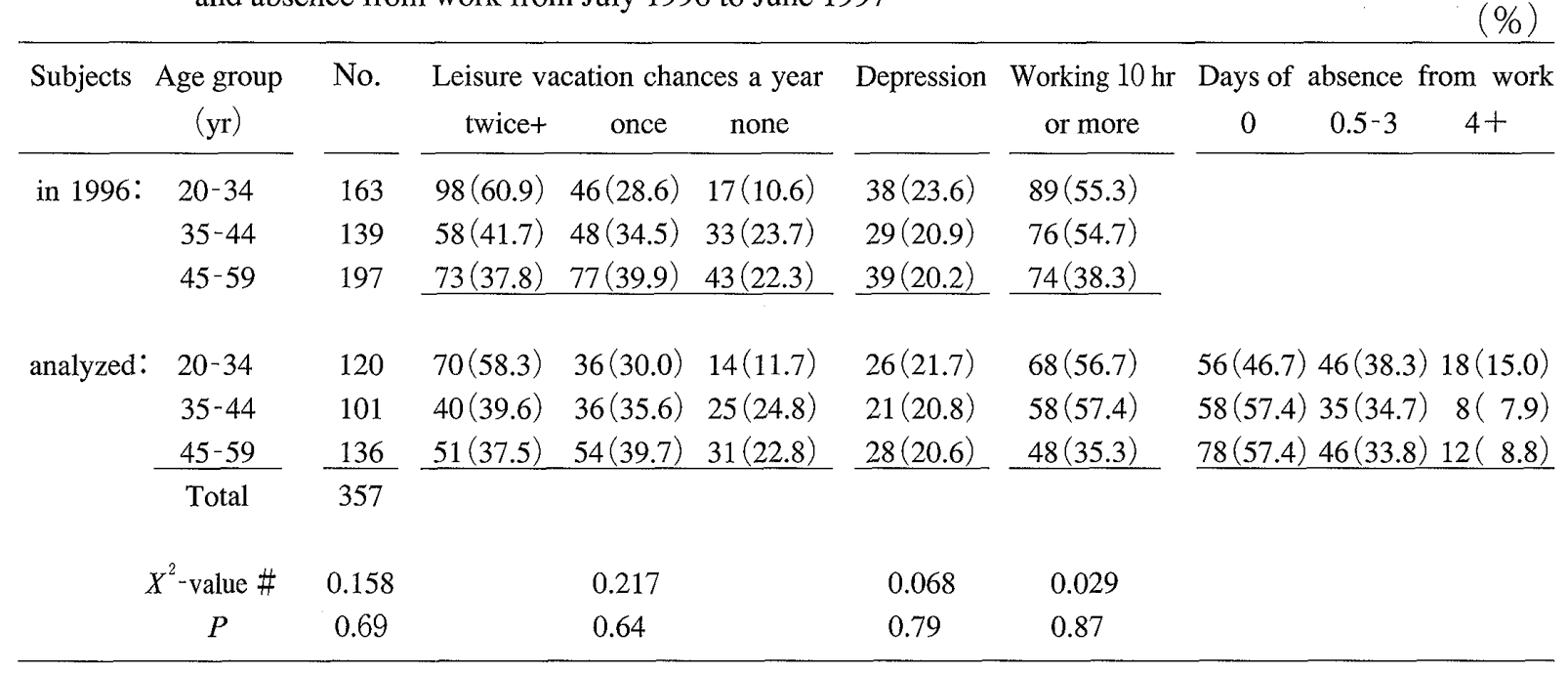

The percentages are indicated in parentheses.

$\$$ The figures are not given for the subjects in 1996 because no question was asked about absence from work in 1996, and see Methods.

\# The Cochran-Mantel-Haenszel statistics tested the differences between the subjects in 1996 and those analyzed.

among all age groups. The percentage of those who worked 10 hours a day or more was the lowest $(35.3 \%)$ in the $45-59$ age group. The percentage of those who took no absences from work within the next one-year period was the lowest $(46.7 \%)$ in the $20-34$ age group.

\section{2 . Association between leisure vacation and depression}

In the 20-34 age group, $50 \%$ of those who had no chance of leisure vacations during the past year, despite legal assurance of a certain number of vacation days, suffered from depression (Table 2). The association between the prevalence of leisure vacation and depression was statistically significant $(P<0.05)$. Also, the prevalence of depression was increasingly associated with the decrease of leisure vacation chances in the $35-44$ and $45-59$ age groups, but these relationships were not significant. Though the percentages of those who indicated depression linearly increased along with the decrease of leisure vacation chances in all the age groups, statistical significance was only found in the $20-34$ age group $(P<0.01)$. The Cochran-Mantel-Haenszel statistics after being adjusted for age and working hours indicated that the association between leisure vacation chances and depression was still significant $(P<0.05)$. In all the age groups, working hours were not significantly associated with depression. 
Table 2. Prevalence of depression in relation to leisure vacation and working hours

\begin{tabular}{|c|c|c|c|c|c|c|c|c|c|c|c|c|c|}
\hline \multirow{3}{*}{$\begin{array}{c}\text { Age group } \\
(\mathrm{yr})\end{array}$} & \multicolumn{8}{|c|}{ Leisure vacation chances } & \multicolumn{5}{|c|}{ Working hours (hr) } \\
\hline & \multicolumn{2}{|c|}{ twice +} & \multicolumn{3}{|c|}{ once } & \multicolumn{3}{|c|}{ none } & \multicolumn{2}{|c|}{ less than 10} & \multicolumn{3}{|c|}{10 or more } \\
\hline & $\mathrm{n}$ & $\%$ & $\mathrm{n}$ & $\%$ & $\mathrm{n}$ & $\%$ & $\mathrm{p}$ & $\mathrm{p} \$$ & $\mathrm{n}$ & $\%$ & $\mathrm{n}$ & $\%$ & \\
\hline $20-34$ & 10 & 14.3 & 9 & 25.0 & 7 & 50.0 & * & $* *$ & 12 & 23.1 & 14 & 20.6 & ns \\
\hline $35-44$ & 7 & 17.5 & 7 & 19.4 & 7 & 28.0 & ns & ns & 6 & 13.9 & 15 & 25.9 & ns \\
\hline $45-59$ & 9 & 17.7 & 11 & 20.4 & 8 & 25.8 & ns & ns & 16 & 18.2 & 12 & 250 & ns \\
\hline Total & 26 & 16.2 & 27 & 21.4 & 22 & 31.4 & $* \#$ & $* *$ & 34 & 18.6 & 41 & 23.6 & ns \\
\hline
\end{tabular}

$\$$ The significance level for the Cochran-Armitage test.

\# The Cochran-Mantel-Haenszel chi-square test adjusted for age and working hours.

${ }^{*}: P<0.05, \quad * *: P<0.01, \quad$ ns: not significant.

\section{3 . Association between depression and absence from work}

Those who suffered from depression tended to take a longer absence from work within the next one-year period than those who did not (Table 3). Those who took no absences from work were consistently more in those who did not suffer from depression than in those who did. In the 20-34 and 45-59 age groups, the associations between depression and absence from work were statistically significant $(P<0.001$ and $P<0.01$, respectively). Even in the 35-44 age group, the percentage of those who took no absences from work within the next year was higher in those who did not suffer from depression than in those who did. The association between those factors was also statistically significant $(P<$ 0.001) after adjustment was made for age.

\section{Breakdown of the subjects}

The subjects were broken down according to the categories of leisure vacation chances, depression (Table 4), and absence from work along with time progression. Under each category of leisure vacation chances (twice or more, once, none), all of the associations between depression and absence from work were significant $(P<0.001, P<0.01$, and $P<0.05$, respectively), and those who suffered from depression tended to take longer absences from work. Along with the decrease of leisure vacation chances, the percentages of those who took no absences from work tended to increase especially in those not suffering from depression, though the number of such subjects were not large.

\section{The results from log-linear analysis}

Among some of the possible models, only the model which contained the interaction terms among leisure vacation chances and depression, depression and absence from work, 
Table 3. Relationship between depression and absence from work

\begin{tabular}{|c|c|c|c|c|c|c|c|}
\hline \multirow{2}{*}{$\begin{array}{c}\text { Age group } \\
(\mathrm{yr})\end{array}$} & \multirow[t]{2}{*}{ Depression } & \multirow{2}{*}{$\begin{array}{c}\text { No of } \\
\text { subjects }\end{array}$} & \multicolumn{5}{|c|}{ Days of absence from work } \\
\hline & & & & 0 & $0.5-3$ & $4+$ & \\
\hline \multirow[t]{3}{*}{$20-34$} & not suffering & 94 & 49 & $(52.1)$ & $39(41.5)$ & $6(6.4)$ & $* * *$ \\
\hline & suffering & 26 & 7 & $(26.9)$ & $7(26.9)$ & $12(46.2)$ & \\
\hline & total & 120 & 56 & $(46.7)$ & $46(38.3)$ & $18(15.0)$ & \\
\hline \multirow[t]{3}{*}{$35-44$} & not suffering & 80 & 47 & $(58.8)$ & $26(32.5)$ & $7(8.8)$ & ns \\
\hline & suffering & 21 & 11 & $(52.4)$ & $9(42.9)$ & $1(4.8)$ & \\
\hline & total & 101 & 58 & $(57.4)$ & $35 \cdot(34.7)$ & $8(7.9)$ & \\
\hline \multirow[t]{3}{*}{$45-59$} & not suffering & 108 & 69 & $(63.9)$ & $32(29.6)$ & $7(6.5)$ & $* *$ \\
\hline & suffering & 28 & 9 & $(32.1)$ & $14(50.0)$ & $5(17.9)$ & \\
\hline & total & 136 & 78 & $(57.4)$ & $46(33.8)$ & $12(8.8)$ & \\
\hline \multirow[t]{3}{*}{ Total $\$$} & not suffering & 282 & 165 & $(58.5)$ & $97(34.4)$ & $20(7.1)$ & $* * *$ \\
\hline & suffering & 75 & 27 & $(36.0)$ & $30(40.0)$ & $18(24.0)$ & \\
\hline & total & 357 & 192 & $(53.8)$ & $127(35.6)$ & $38(10.6)$ & \\
\hline
\end{tabular}

The percentages are indicated in parentheses.

$\$$ The Cochran -Mantel-Haenszel chi-square test adjusted for age was applied.

ns:not significant, $\quad * *: P<0.01, \quad * * *: P<0.001$.

Table 4. Breakdown of the subjects according to the categories of leisure vacation, depression and absence from work

\begin{tabular}{|c|c|c|c|c|c|c|}
\hline \multicolumn{3}{|c|}{1996 survey } & \multicolumn{4}{|c|}{1997 survey } \\
\hline \multirow{2}{*}{$\begin{array}{c}\text { Leisure vacation } \\
\text { chances }\end{array}$} & \multirow{2}{*}{\multicolumn{2}{|c|}{ Depression }} & \multicolumn{3}{|c|}{ Days of absence from work } & \\
\hline & & & 0 & $0.5-3$ & 4 or more & \\
\hline \multirow[t]{3}{*}{ twice or more } & & $161(45.1)$ & $76(47.2)$ & $62(38.5)$ & $23(14.3)$ & \multirow{3}{*}{$* * *$} \\
\hline & not suffering & $135(83.9)$ & $67(49.6)$ & $55(40.7)$ & $13(9.6)$ & \\
\hline & suffering & $26(16.1)$ & $9(34.6)$ & $7(26.9)$ & $10(38.5)$ & \\
\hline \multirow[t]{3}{*}{ once } & & $126(35.3)$ & $71 \quad(56.3)$ & $45(35.7)$ & $10(7.9)$ & \multirow{3}{*}{$* *$} \\
\hline & not suffering & $99(78.6)$ & $62(62.6)$ & $32(32.2)$ & $5(5.1)$ & \\
\hline & suffering & $27(21.4)$ & $9(33.3)$ & $13(48.2)$ & $5(18.5)$ & \\
\hline \multirow[t]{3}{*}{ none } & & $70(19.6)$ & $45(64.3)$ & $10(28.6)$ & $5(7.1)$ & \multirow{3}{*}{$*$} \\
\hline & not suffering & $48(68.6)$ & $36(75.0)$ & $10(20.8)$ & $2(4.2)$ & \\
\hline & suffering & $22(31.4)$ & $9(40.9)$ & $10(45.5)$ & $3(13.6)$ & \\
\hline
\end{tabular}

The percentages are indicated in parentheses.

$*: P<0.05, \quad * *: P<0.001, \quad * * *: P<0.001$. 
and leisure vacation chances and absence from work fitted the data, except for the full model. All the combinations of interaction terms among the factors were statistically significant (Fig. 1 ), and all combinations of the factors were associated with irrespective of the level of the remaining factor. The parameters estimated between vacation and depression were positive (Table 5), and this meant that the observed number of those who did not suffer from depression were more that those expected in those who took more leisure vacations. The parameters between depression and absence from work were also positive. This indicated that the observed number of those who had no absences from work were more than those who did not suffer from depression. On the other hand, the parameters between leisure vacation chances and absence from work were negative, and the observed number of those who took no absence from work were less than those expected among those who took more leisure vacations.

Fig. 1. Scheme of interaction between leisure vacation, depression, and absence from work : the results from the log-linear analysis.

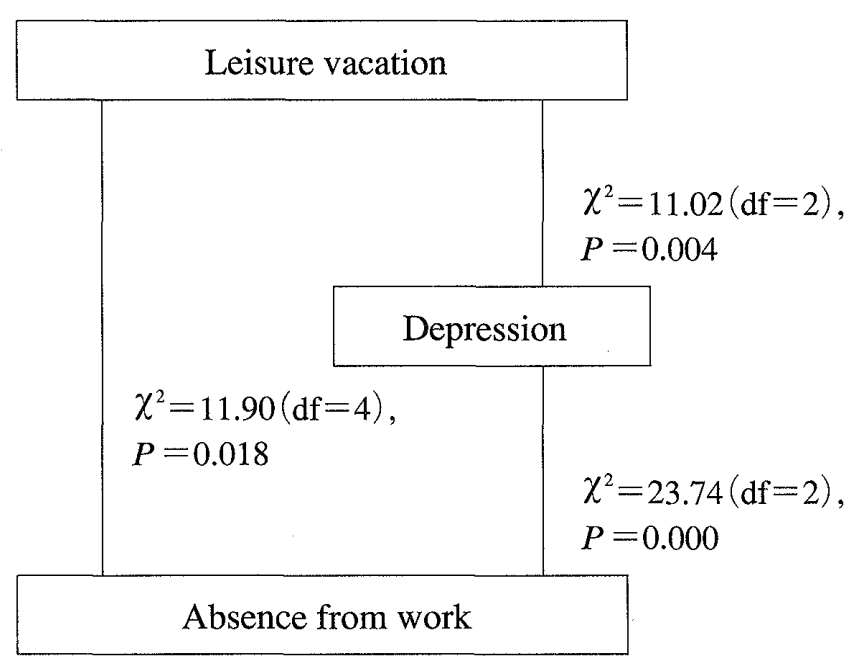

The chi-squared values are for the interaction terms, $\mathrm{df}$ is degree of freedom and $P$ is probability. 
Table 5. Parameter estimates and standard errors : the results from the log-linear analysis

\begin{tabular}{cccccc}
\hline Parameter & & & Estimate & SE & \\
\hline Leisure vacation & $\lambda(\mathrm{V}) 11$ & & 0.37 & 0.10 & $* * *$ \\
& $\lambda(\mathrm{V}) 12$ & & 0.10 & 0.11 & $\mathrm{~ns}$ \\
Depression & $\lambda(\mathrm{D}) 11$ & & 0.44 & 0.08 & $* * *$ \\
Absence from work & $\lambda(\mathrm{A}) 11$ & & 0.57 & 0.10 & $* * *$ \\
Vacation $*$ depression & $\lambda(\mathrm{A}) 12$ & & 0.30 & 0.10 & $* *$ \\
Depression $*$ absence & $\lambda(\mathrm{VD}) 11$ & & 0.29 & 0.10 & $* *$ \\
& $\lambda(\mathrm{VD}) 21$ & & 0.01 & 0.10 & $\mathrm{~ns}$ \\
Vacation $*$ absence & $\lambda(\mathrm{DA}) 11$ & & 0.46 & 0.10 & $* * *$ \\
& $\lambda(\mathrm{DA}) 12$ & & 0.07 & 0.10 & $\mathrm{~ns}$ \\
& $\lambda(\mathrm{VA}) 11$ & & -0.39 & 0.12 & $* *$ \\
& $\lambda(\mathrm{VA}) 21$ & & -0.04 & 0.12 & $\mathrm{~ns}$ \\
& $\lambda(\mathrm{VA}) 22$ & & 0.04 & 0.13 & $\mathrm{~ns}$ \\
& & & & 0.13 & $\mathrm{~ns}$ \\
\hline
\end{tabular}

SE: Standard error.

ns: not significant, $\quad * *: P<0.01, \quad * * *: P<0.001$.

Model equation adopted:

$\ln m(\mathrm{ijk})=\mu+\lambda(\mathrm{V})+\lambda(\mathrm{D})+\lambda(\mathrm{A})+\lambda(\mathrm{VD})+\lambda(\mathrm{VA})+\lambda(\mathrm{DA})$

The left term, $\mathrm{m}$ (ijk), is the Poisson $\log$ mean for the $i$ th, $j$ th and $k$ th cell in a multidimensional contingency table.

$\mathrm{V}, \mathrm{D}$, and $\mathrm{A}$ stand for leisure vacation, depression and absence from work, respectively, and $\lambda(V), \lambda(D), \lambda(A)$ are parameters for each factor.

$\lambda(\mathrm{VD}), \lambda(\mathrm{VA})$, and $\lambda(\mathrm{DA})$ are interaction terms. For example, $\lambda(\mathrm{V}) 11$ represents the parameter for the first row and the first column cell, and $\lambda(\mathrm{V}) 12$ is that for the first row and the second column cell.

\section{Discussion}

The subjects in this investigation were male white-collar employees who were employed by a large industrial company, and they seemed to take for granted the legal and institutional regulations for vacation given to them. The authors took notice of the chance of vacations taken as leisure, and not a few subjects replied that they had no chance to take a leisurely vacation within the past year (see Table 1). This, of course, does not mean they had no vacation days, and the figures are naturally to be interpreted that such employees have a constantly busy schedule year round. Japanese labor statistics show that male white-collar employees in large companies work longer hours as mentioned in the Introduction [30, 33, 49, 50]. Scheduled working hours are surely fewer in large companies than in small ones, but total working hours (scheduled and non-scheduled) are longer in the former because of more nonscheduled hours. Moreover, a time budget survey [51] has found that white-collar employees work longer hours compared to blue-collar workers. As for paid vacations for white- 
collar employees, no available statistics were found. Though their conditions for taking vacations can be estimated through the statistics above, the figures found in our investigation seemed not to be uncommon. On the other hand, the G-18 was utilized to determine whether the subjects were depressive or not. Depression was an indicator of psychological health status and it must be differentiated from clinical depression as described in the Introduction. The prevalence of those who were judged to be depressive did not differ largely from that reported in the previous examination [37], though the percentages of depression calculated according to the method shown by Goldberg were not indicated in the report.

Through this investigation, the causal relationship among leisure vacation chances, depression, and absence from work was examined. As shown in Table 2, leisure vacation was linearly related to a decrease in depression through all the age groups, and this was also true after age and working hours were adjusted. Lounsbury et al . [45] observed the change of work and non-work outcome levels before and after vacation, and ascertained an alleviating effect in the post-vacation period. They found that satisfaction level during vacation affected job and life satisfaction, and that length of vacation, nine days on average in their subjects, did not influence job satisfaction, turnover intention, and other job-related variables in post-vacation periods. Westman et al . [27] followed-up 76 clerical employees and observed the change of job stressors and burnout levels before, during, and after two weeks of vacation. They also found a respite effect due to vacation, and job stressor and burnout level decreased during vacation compared to pre-vacation periods, though both returned to the previous level at least three weeks after the end of vacation. They, moreover, recognized that the satisfaction level caused by vacation influenced the burnout level in the subjects.

Through the above investigations, it can be induced that two factors have to be taken into consideration regarding vacation effects on psychological status. First, frequent taking of vacations may positively affect employees' mental well-being, because vacation affects psychological aspects and a respite effect does not last long. Second, a satisfactory vacation could bring greater relief from stress than a non-satisfactory vacation. The number of leisure vacation chances was investigated in our study. The items questioned substantially included subjects' satisfaction with vacations because the question regarding this point was asked. Therefore, frequent taking of satisfactory vacations may explain the decreasing tendency of depression. Of course, the length or the timing of vacations naturally can influence whether employees are satisfied with their vacations. Whether vacations are long enough or how many vacation days are sufficient to decrease the tendency of depression must be examined hereafter.

The association between leisure vacation chances and depression was small in the older subjects compared to the younger subjects (Table 2). Since almost all the older subjects were managerial employees, the possibility could not be denied that other factors that originated from organizational life had certain effects on these subjects. For example, Burke [46] summarized the sources of stress in white-collar workers, and stated that "the experi- 
ence of certain features of organizational and family life, and realities of the aging process (mid-life), were antecedents of personal and social alienation among managers and professionals." In our subjects, because organizational experience was associated with age due to the seniority system (see Methods), no items concerning organizational issues were prepared. The kind of questions that should be asked to middle-aged employees is worth considering.

Whether the subjects suffered from depression or not was significantly related to the decrease in days of absence from work (Table 3). This was concordant with the results from the large epidemiologic investigations as mentioned in the Introduction, and according to the follow-up study design, was interpreted as depression affecting absence from work during the next year period. An intervention study using blue-collar workers also reported that a stress reduction program was effective for depressive symptoms and decreased the amount of sick leave [47]. When the results of the literature which explored the association between depression and sick leave and the prospective study design here were taken into account, a causal association where depression led to an increase in absences from work seemed to be valid. Though those subjects aged 35-44 years did not show an explicit association with those two factors, white-collar employees in this age group are serious about their job advancement process in this company, and such a situation might prevent them from taking more vacation days.

Time-serial and comprehensive relationship among leisure vacation chances, depression, and absence from work were examined in the contingency table (Table 4), and also were confirmed using a log-linear analysis (Fig. 1, Table 5). Those who took frequent leisure vacations tended not to suffer from depression, and those who did not suffer from depression tended to take fewer absent days from work compared with those who did. The trends of the parameters estimated in the log-linear analysis coincided with the results indicated in Table 2, Table 3, and Table 4. However, the parameter between leisure vacation and absence from work was inconsistent with the results from the contingency tables.

The parameters between leisure vacation and absence from work were negative, and, this could be interpreted that the more leisure vacations were taken, less was the percentage of those who took no absences from work irrespective of the presence of depression. This seemed to be contradictory to the previous findings where leisure vacation was related to a lower prevalence of depression and consequent fewer absent days from work. This study, however, was designed as a follow-up investigation. It is substantially meaningless to interpret directly the association between leisure vacation and absence from work without considering an intermediate step, depression, in the causal pathway [44]. A breakdown of the subjects could also explain this association (Table 4). Those who took no leisure vacations tended to take no absences from work. Though this was found both in those who suffered from depression and those who did not $(40.9 \%$ and $75.0 \%$, respectively), it was more remarkable in those who did not suffer from depression. Therefore, when the association between leisure vacation and absence from work were examined without considering depression, 
those who took fewer vacations naturally seemed to have fewer absent workdays: Inversely, more vacation chances led to a fewer number of those who took no absences from work.

Using a representative Hungarian population, Kopp et al . [48] examined the hypothesis that consequent emotional disturbances due to failure to cope with various socioeconomic events contributed to working disability or sickness rates. A hierarchical log-linear analysis proved that depression mediated between certain socioeconomic factors and sick leave. Though their investigation and our study had a different study design and the factors examined were different, their results seemed to be supportive of ours. Depression was reported to tend to be prolonged in relation to socioeconomic factors [38]. In cases where demanding working situations are unchangeable, a long-lasting overload of work and fewer leisure vacation chances could possibly correlate with absence from work mediated by depression.

The findings here were not inconsistent with those of related reports as discussed above. White-collar workers nowadays make up over half of all the employees in developed countries [52], and a relatively consistent workload for white-collar workers has become a subject of discussion $[52,53]$. In this study, only male employees were examined. Further investigations taking into account wider work-related factors and the nature of vacations in various subjective groups and occupational settings including female employees are expected. Leisure vacation was determined based on the workers own complaints, and this information might be helpful when considering the psychological well-being of employees in the workplace.

\section{References}

1. Johnson J, Weissman MM \& Klerman GL (1992) : Service utilization and social morbidity associated with depressive symptoms in the community. JAMA $267:$ 1478-1483

2 . Ormel J, VonKorff M, Ustum B, Pini S, Korten A \& Oldehinkel T (1994) : Common medical disorders across cultures. Results from the WHO collaborative study on psychological problems in general health care. JAMA 272: 1741-1748

3 . Lepine JP, Gastpar M, Mendlewicz J \& Tylee A (1997) : Depression in the community : the first pan-European study DEPRES (Depression Research in European Society) . Int Clin Psychopharmacol 12: $19-29$

4 . Greenberg PE, Stiglin LE, Finkelstein SN \& Berndt ER (1993) : The economic burden of depression in 1990. J Clin Psychiatry 54: 405-418

5 . Greenberg PE, Stiglin LE, Finkelstein SN \& Berndt ER (1993): Depression: A neglected major illness. J Clin Psychiatry $54: 419-424$

6. Santiago JM (1993) : The costs of treating depression. J Clin Psychiatry 54: 425-426

7. Conti DJ \& Burton WN (1994) : The economic impact of depression in a workplace. Journal of Occupational Medicine $36: 983-988$

8. Mcdowell I \& Kristjasson E (1996) : Depression. In : Measuring Health (McDowell I \& Newell C, 
ed). 2nd ed. Oxford University Press, London pp 238-242

9 . Boumendil E \& Tubert-Bitter P (1995) : Depression-induced absenteeism in relation to antihyperlipidemic treatment : A study using GAZEL cohort data. Epidemiology $6: 322-325$

10. Souetre E, Lozet H \& Cimarosti I (1997) : Predicting factors for absenteeism in patients with major depressive disorders. European Journal Epidemiology 13 : 87-93

11. Marmot MG, Smith GD, Stansfeld S et al (1991) : Health inequalities among British civil servants: the Whitehall II study. Lancet 337 : 1387-1393

12. North F, Syme SL, Feeney A et al (1993) : Explaining socioeconomic differences in sickness absence: the Whitehall II study. BMJ 306: 361-366

13. Goldberg D (1972): The detection of psychiatric illness by questionnaire. Oxford University Press, London $126 \mathrm{pp}$

14. Whippen DA \& Canellos GP (1991) : Burnout syndrome in the practice of oncology: Results of a random survey of 1,000 oncologists. J Clin Oncol 9: 1916-1920

15. Meire ST (1984): The construct validity of burnout. Journal of Occupational Psychology 57 : $211-219$

16. Linn LS, Yager J, Cope D \& Leake B (1985) : Health status, job satisfaction, job stress and life satisfaction among academic and clinical faculty. JAMA 254: 2775-2782

17. Lloyd S, Streiner D \& Shannon S (1994) : Burnout, depression, life and job satisfaction among Canadian emergency physicians. J Emerg Med 12: 559-565

18. Schor JB (1991): The overworked American: The unexpected decline of leisure. Basic Books, New York $247 \mathrm{pp}$

19. Tarumi K, Hagihara A \& Morimoto K (1992) : Working hours and commuting time from the viewpoint of health care management in occupational settings - An investigation of the effects on lifestyle. Japanese Journal of Public Health 39 : 163-171

20. Tarumi K, Hagihara A \& Morimoto K (1993) : An inquiry into the relationship between job strain and blood pressure in male white-collar workers. Japanese Journal of Industrial Health $35: 269-$ 276

21. Tarumi K, Hagihara A \& Morimoto K (1998) : An investigation into the effects of vacations on the health status in male white-collar workers. Environmental Health and Preventive Medicine 3: 2330

22. Hagihara A, Tarumi K, Miller AS \& Morimoto K (1997): Type A and Type B behaviors, work stressors, and social support at work. Prev Med 26: 486-494

23. Hagihara A, Tarumi K \& Morimoto K (1997) : Type A and Type B behaviors and factors related to job satisfaction among male white-collar workers. Environmental Health and Preventive Medicine 2 : $139-144$

24. Leisure Development Center of Japan (1997) : Investigation of lifestyle and needs in long vacations. Leisure development center, Tokyo pp 33-51

25. Caldwell LL \& Smith EA (1988) : Leisure: An overlooked component of health promotion. Can J Public Health 79 : S44-S48 
26. Kirkcaldy BD \& Cooper CL (1993): The relationship between work stress and leisure style: British and German managers. Human Relations 46: 669-680

27. Westman M \& Eden D (1997) : Effects of a respite from work on burnout: Vacation relief and fadeout. J Appl Psychol 82: 516-527

28. Goldberg D, Bridges K, Duncan-Jones P \& Grayson D (1988) : Detecting anxiety and depression in general medical settings. BMJ 297: 897-899

29. Ministry of Labour of Japan (1997) : Labour standards law. In : Labour laws of Japan, 1995. Romu Gyosei Kenkyusho, Tokyo 811 pp

30. Ministry of Labour (1997) : White paper on labour 1996. The Japan Institute of Labour, Tokyo $111 \mathrm{pp}$

31. Saito Y (1989) : Ergology and the problem of leisure for Japanese workers. J Hum Ergol 18 : $1-2$

32. National Defense Counsel for Victims of Karoshi (1990): Karoshi, when the "corporate worrier" dies. Mado-Sha, Tokyo pp 64-76

33. Matsubara N (1996) : Enforcement of taking leisure vacation (Yutori Kyuka No Susume). Romu Gyosei Kenkyusho, Tokyo pp 11-28, 55-89, 162-171

34. Parker S (1971): The future of work and leisure. Granada Publishing, London $160 \mathrm{pp}$

35. Dumazedier J (1967) : Toward a society of leisure. Collier-Macmillan, London pp 14-17

36. Asher HB (1976) : Causal modeling. In Series: Quantitative applications in the social sciences (1st ed). SAGE publications, Beverly Hills $80 \mathrm{pp}$

37. Mackinnon A, Christensen H, Jorm AF et al (1994) : A latent trait analysis of an inventory designed to detect symptoms of anxiety and depression using an elderly community sample. Psychol Med 24: 977-986

38. Murphy JM, Oliver DC, Monson RR et al (1991) : Depression and anxiety in relation to social status. Arch Gen Psychiatry 48: 223-229

39. Spurgeon A, Harrington JM \& Cooper CL (1997) : Health and safety problems associated with long working hours: A review of the current position. Occupational and Environmental Medicine $54: 367-375$

40. Everitt BS (1977) : The analysis of contingency tables. Chapman \& Hall, London $128 \mathrm{pp}$

41. Schlesselman JJ \& Stolley PD (1982) : Case-control studies-Design, conduct, analysis. Oxford University Press, Oxford $346 \mathrm{pp}$

42. McCullagh P \& Nelder JA (1996) : Generalized linear models. Chapman \& Hall, London pp $193-244$

43. SAS Institute Inc. (1988) : SAS/STAT user's guide. SAS Institute Inc., Cary $1077 \mathrm{pp}$

44. Rothman KJ (1986) : Modern epidemiology (1st ed). Little, Brown and Company, Boston pp $89-97$

45. Lounsbury JW \& Hoopes LL (1986) : A vacation from work: Changes in work and nonwork outcomes. J Appl Psychol 71: 392-401

46. Burke R (1989) : Sources of managerial and professional stress. In : Causes, coping and conse- 
quences of stress at work. (Cooper CL \& Payne R, ed). John Wiley \& Sons, Chichester pp 77114

47. Karasek RA (1979) : Job demands, job decision latitude, and mental strain: Implications for job redesign. Administrative Science Quarterly 24: 285-311

48. Kopp MS, Skrabski A \& Szedmak S (1995) : Socioeconomic factors, severity of depressive symptomatology, and sickness absence rate in the Hungarian population. J Psychosom Res 39: 10191029

49. Ministry of Labour of Japan, Policy Planning and Research Department, Ministry's Secretariat (1998) : Year book of labour statistics 1996. Romu Gyosei Kenkyusho, Tokyo 389 pp

50. Management and Coordination Agency, Department of Statistics (1996) : Annual report on the labour force survey. Nippon Tokei Kyokai, Tokyo $249 \mathrm{pp}$

51. Makita T (1996): Life activities and time allotment. In : Time budget of the Japanese, 1995 (Nippon Jin No Seikatsu Jikan 1995). (NHK Institute of Broadcast and Culture, ed). Nippon Hoso Shupan Kyokai, Tokyo pp 25-42

52. Kon A (1994) : The Change of the structure of employment. In : International comparison of labour statistics (Yoichi I, ed). Azusa Shuppan Sha, Tokyo pp 17-45

53. Ministry of Labour of Japan, Policy Planning and Research Department (1998) : Annual report of the monthly labour survey. Romu Gyosei Kenkyusho, Tokyo 273 pp 
余㗇休㗇，抑うつならびに欠勤の因果関係に関する一考察

垂水 公男 ${ }^{1}$ 萩原 明人 ${ }^{2}$

産業医科大学 進路指導部

${ }^{2}$ 九州大学大学院医学研究科 医療システム学教室

要旨：抑うつは, 職場で最も頻繁に見受けられる心理的な問題の一つである. 文献的考察 ならびに著者らが行ってきた過去の調查結果からは，職場の労働負荷は抑うつを介 して欠勤の増加と関連していることが推測されてきている。そこで，こうした一連 の関連を検証するために男子ホワイトカラーを対象にした迫跡研究を実施した。と ころで, 労働負荷と健康についての著者らの研究からは, 休暇取得が心理面の負担 を軽減する一つの重要な可能性として上げられてきていた。 そこで, 1996年 6 月に, 自記式の調査票を用いて過去 1 年間の余㗇として取得された休暇の機会と抑うつと の関連性を調べた。この調査対象者をさらに 1 年間追跡して，この期間の欠勤日数 を調査した．分析対象として有効であった20-59歳の男性357名について，休㗇，抑 うつ, 欠勤の関連性を相関ならびに対数線形分析によって検討し, 次のような結果 が得られた。すなわち, 余暇休㗇の取得機会の少なさは抑うつの存在と相関し，抑 うつは欠勤の増加に関連していた。これらの関係は年齢を調整した場合にも成立し ていた．余㗇としての休㗇取得は労働時間のような他の労働関連要因とは独立であ り，その影響を探求することは職場での心理負担への対応を考光る上で有意義であ ると考えられた。

J UOEH（産業医大誌）21（4）：289-307（1999） 